\title{
Chemical and biological studies of Lobelia flaccida (C. Presl) A.DC leaf: a medicinal plant used by traditional healers in Eastern Cape, South Africa
}

\author{
Siviwe Stolom ${ }^{1}$, Idris A Oyemitan ${ }^{1,2}$, Reuben Matewu ${ }^{3}$, Opeoluwa O Oyedeji ${ }^{4}$, \\ Samuel 0 Oluwafemi ${ }^{5}$, Benedicta N Nkeh-Chungag ${ }^{6}$, Sandile P Songca ${ }^{7}$ and \\ Adebola O Oyedeji ${ }^{1 *}$ \\ ${ }^{1}$ Department of Chemical \& Physical Sciences, Faculty of Natural Sciences, Walter Sisulu University, Mthatha, Republic of \\ South Africa, ${ }^{2}$ Department of Pharmacology, Faculty of Pharmacy, Obafemi Awolowo University, Ile-Ife, Osun State, Nigeria, \\ ${ }^{3} 1124$ Buchanan Street, Ginsburg, King Williams Town, Eastern Cape, ${ }^{4}$ Department of Chemistry, Faculty of Science \& \\ Agriculture, University of Fort Hare, Alice, ${ }^{5}$ Department of Applied Chemistry, Faculty of Science, University of Johannesburg, \\ ${ }^{6}$ Department of Biological and Environmental Sciences, Faculty of Natural Sciences, ${ }^{7}$ Department of Chemical \& Physical \\ Sciences, Faculty of Natural Sciences, Walter Sisulu University, Mthatha, Republic of South Africa
}

*For correspondence: Email: aoyedeji@wsu.ac.za; Tel: +27475021951, +27764260279

Received: 1 October 2015

Revised accepted: 4 July 2016

\begin{abstract}
Purpose: To investigate the phytochemical constituents, acute toxicity and biological activities of Lobelia herb (dried leaf of Lobelia flaccida; family: Campanulaceae), a popular medicinal agent used to manage pain and epilepsy among other indications in Eastern Cape Region of South Africa.

Methods: Essential oil (EO) obtained from the dried leaf was analysed with gas chromatography-mas spectroscopy GC/MS while an infusion extract of the herb was obtained by soaking in hot boiled water $\left(100^{\circ} \mathrm{C}\right)$ for $24 \mathrm{~h}$, filtered and the filtrate dried in vacuo. Phytochemical screening of the infusion extract was performed to detect the presence of secondary plant metabolites and relative abundance of some of the metabolites. The aqueous extract was evaluated for oral (p.o.) acute toxicity $\left(L D_{50}\right)$ using the Lorke's method [30]; thereafter the extract was tested for anti-inflammatory activity on carrageenaninduced rat paw oedema at 250 and $500 \mathrm{mg} / \mathrm{kg}$, p.o., normal saline and aspirin (100 mg/kg, p.o.) used as negative and positive controls respectively. Finally, the extract at 500 and $1000 \mathrm{mg} / \mathrm{kg}$, p.o. was tested for anticonvulsant activity on pentylene tetrazol (85 mg/kg, intraperitoneally)-induced convulsion model in mice, normal saline and diazepam (1 mg/kg, i.p.) served as negative and positive control groups respectively.

Results: EO yield was $0.022 \% \mathrm{w} / \mathrm{w}$ and the two major compounds identified were acetophenone (26.37\%) and caryophyllene (17.35\%). Phytochemical screening showed high concentration of alkaloids, saponins and flavonoids among other constituents. $L D_{50}$ of the aqueous extract was $\geq 5000$ $\mathrm{mg} / \mathrm{kg}$ per oral while the aqueous extract exhibited significant $(p<0.01)$ anti-inflammatory activity on carrageenan-induced rat paw oedema comparable to aspirin but insignificant anticonvulsant activity on pentylene tetrazol-induced convulsion when compared with diazepam.

Conclusion: Lobelia herb is non-toxic, and possesses significant anti-inflammatory and mild anticonvulsant activities. It is suggested that the essential oil of this herb should be screened for pharmacological activities.
\end{abstract}

Keywords: Lobelia flaccida, Essential oil, Gas chromatography/mass spectroscopy analysis , Infusion extract, Acute toxicity, Anti-inflammatory, Anti-convulsant

Tropical Journal of Pharmaceutical Research is indexed by Science Citation Index (SciSearch), Scopus, International Pharmaceutical Abstract, Chemical Abstracts, Embase, Index Copernicus, EBSCO, African Index Medicus, JournalSeek, Journal Citation Reports/Science Edition, Directory of Open Access Journals (DOAJ), African Journal Online, Bioline International, Open-J-Gate and Pharmacy Abstracts 


\section{INTRODUCTION}

The contribution of natural products particularly medicinal plants to discovery of novel drugs have been well highlighted [1] and Newman et al [2] reported that research on natural products accounted for about $48 \%$ of all natural productderived compounds between 1981 and 2002. Furthermore, Jones et al [3] revealed that majority of plant-related drugs on the pharmacy shelf as at 1993 actually emanated from ethnomedicinal application of most species that were indicated for the same therapeutic uses. Crude herbs which have long been used as the basis for traditional medicines worldwide are still invaluable now [4]. The role of traditional medicine in mitigating disease burden and poverty in the African continent has been emphasized and extended to include increasing the economic well-being and healthcare accessibility of communities.

Lobelia commonly known as Indian tobacco is a genus of flowering plants comprising about 415 species (family: Campanulaceae) with subtle distribution in tropical-warm temperate regions of the world [5]. L. inflata is regarded as the most important variety in this family consisting of several species including $L$. cardinalis, $L$. erinus, $L$. spitaca, $L$. siphilitica, $L$. puberula and $L$. appendiculata [6]. Sixty-nine species occur in South Africa, found throughout the country growing in a variety of habitats $[7,8]$. One of the commonest species found in the Eastern Cape of South Africa is L. flaccida (C. Presl) A.DC, family: Campanulaceae known as itshilizi in Ixhosa language $[8,9]$ and is the specie investigated in this study. Traditionally, different Lobelia species has been used for bronchitis and asthma, topically for myositis and rheumatic nodules, as a diuretic, antidote and as carcinostatic agents for stomach cancer in Chinese folk medicine [10,11]. Lobelia siphilitica and $L$. cardinalis were historically used in the treatment of syphilis in North America [12]. Although several studies have been undertaken to evaluate lobeline (an alkaloid from Lobelia) as anti-smoking drug, the results obtained showed that it was ineffective in helping people quit smoking with conflicting results [13].

Reports on the chemical constituents of Lobelia species confirmed alkaloids such as lobeline, norlobelanine; flavonoid compounds (apigenin, luteolin, quercetin), and coumarins; and essential oil [14]. Biological studies on Lobelia species showed several activities including antimicrobial [15], antidepressant [16] anticancer [11] and antiepileptic [17] and analgesic and antivenom potentials [18].
The people of the Eastern Cape of South Africa depend largely on the use of medicinal plants born out of strong belief that they are effective to treat many diseases [19]. The Department of Science and Technology, South Africa, initiated the Indigenous Knowledge System (IKS) Project in 2002 in its bid to bridge the gap between the herbal practitioners and the academia, improve the health care system in the rural areas and advance herbal practices in the community.

This is the first study reporting chemical composition and biological activities of this particular species from the Eastern Cape and the aim was to investigate the chemical composition of the essential oil; screen the infusion extract for secondary metabolites; and then determine the acute toxicity profile, anti-inflammatory and anticonvulsant $[8,11]$ activities of the crude infusion extract of Lobelia flaccida. Thus, this study is expected to generate new information and to validate the use of this plant in South African herbal practice.

\section{EXPERIMENTAL}

\section{Plant collection, and extraction of essential oil and infusion extract}

Dried leaves of Lobelia were collected from the Herbal Practitioner on $3^{\text {rd }}$ July 2014 at Ginsberg, King Williams Town, Eastern Cape, South Africa. The leaves were used for the extraction of the essential oil and infusion extract. The dried leaves of Lobelia were identified by Dr. K Immelman, Herbarium Unit, Department of Botany, Walter Sisulu University (WSU), Mthatha. Essential oil of Lobelia flaccida dried leaf was obtained by hydrodistillation using a cleavenger-like apparatus and stored in a vial, protected from light until sent for analysis. Infusion extract of the leaves was obtained according to herbal practitioner's directive. Briefly, $100 \mathrm{~g}$ of the dried plant material was grounded into coarse powders and soaked in boiling water with continuous stirring and allowed to infuse for $24 \mathrm{~h}$. Thereafter, it was filtered using Whatman filter paper; a portion was kept for the phytochemical screening, while the remaining portion was dried in an oven at $35^{\circ} \mathrm{C}$.

\section{Phytochemical screening}

For qualitative screening, aqueous extract of Lobelia flaccida leaf was used while the powdered leaf was used for quantitative screening according to the method described by Mir et al [20]. 


\section{Qualitative screening}

The infusion filtrate was used for the qualitative analysis to detect the presence of secondary metabolites including tannins, saponins, flavonoids, terpenoids, alkaloids, phenols, phytosterols, glycosises, anthraquinones, phlobatanninsand proteins/amino acids in the aqueous leaf extract of Lobelia flaccida [20].

\section{Analysis of essential oil of Lobelia leaf}

\section{Gas chromatography- flame ionization detector (GC-FID) analysis}

GC analysis was carried out on a Perkin-Elmer 8500 gas chromatograph with a FID detector with a SGE BP X5 column that is $30 \mathrm{~m}$ in length with a film thickness of $0.25 \mu \mathrm{m}$ and diameter 0.25 $\mathrm{mm}$ ID. The operating conditions were as follows: carrier gas, nitrogen with a flow rate of 3.0 $\mathrm{ml} / \mathrm{min}$; column temperature, $60-275{ }^{\circ} \mathrm{C}$ at 4 ${ }^{\circ} \mathrm{C} / \mathrm{min}$; injector and detector temperature, $280{ }^{\circ} \mathrm{C}$ -; volume injected $0.1 \mu \mathrm{l}$ of the oil; split ratio, $1: 50$.

\section{GC-MS analysis}

GC/MS analysis of the oil was performed on a GCMS-QP2010 Gas Chromatography- mass spectrometer system operating in El mode at 70 $\mathrm{eV}$, equipped with a HP-5 MS fused silica capillary system with a $5 \%$ phenylmethylsiloxane stationary phase. Capillary column parameter was $30 \mathrm{~m}$ by $0.25 \mathrm{~mm}$, film thickness $0.25 \mu \mathrm{m}$. The initial temperature of the column was $70^{\circ} \mathrm{C}$ and was heated to $250{ }^{\circ} \mathrm{C}$ at a rate of $5{ }^{\circ} \mathrm{C} / \mathrm{min}$. The final temperature was kept at $450{ }^{\circ} \mathrm{C}$ and run time of $68 \mathrm{~min}$. Helium was used as the carrier gas at a flow rate of $1 \mathrm{ml} / \mathrm{min}$. The split ratio was 100:1. Scan time was $68 \mathrm{~min}$ with a scanning range of 35 to $450 \mathrm{amu}$. One microliter $(1 \mu \mathrm{l})$ of the diluted oil (in hexane) was injected for analysis. $\mathrm{N}$-alkane of $\mathrm{C} 8$ to $\mathrm{C} 30$ was run under the same condition for Kovat indices determination.

\section{Experimental animals}

Mice and rats were obtained from the South African Vaccine Initiative, Johannesburg and kept at the Animal Holding Facility, Zoology Department, Walter Sisulu University WSU. Male and female Wistar rats $(200-300 \mathrm{~g})$ were randomly selected $(n=6)$ for the anti-inflammatory test. Swiss mice of both sexes (25-35 g; $n=6$ ) were also selected for the acute toxicity and the anticonvulsant tests. They were kept under standard laboratory conditions and had free access to rat chow and water. Food was however withheld overnight prior to experiments while water was provided ad libitum. This study was approved by the Department of Higher Education, WSU (Ref: DVC (AA\&R) DRD/SREC) The study was carried out in accordance with the "Principles of Laboratory Animal Care", NIH publication no. 85-23, revised 1985.

\section{Acute toxicity}

Acute toxicity effect of the infusion extract of the leaves of Lobelia flaccida was assessed in mice using the oral route (p.o.) according to Lorke's method [21]. The method involved using only thirteen (13) animals and was divided into 2 phases. The first phase consists of three (3) subgroups $(n=3)$ at dose levels of 10,100 and 1000 $\mathrm{mg} / \mathrm{kg}$. The second phase involved four $(\mathrm{n}=1)$ dose levels of 1000, 1600, 2900 and $5000 \mathrm{mg} / \mathrm{kg}$ respectively. Immediately after treatment, each mouse was placed inside the Plexiglas cage and observed for immediate effects up to $30 \mathrm{~min}$ and thereafter for $24 \mathrm{~h}$ for lethal effects culminating into death. The $\mathrm{LD}_{50}$ of the extract was estimated as the geometric mean of the lowest dose causing death and the highest dose causing no death according to Eq 1.

$L D_{50}=\sqrt{ }(A B)$

where $A$ is the maximum dose producing $0 \%$ death and $B$ is the lowest dose that produced $100 \%$ death.

\section{Anti-inflammatory activity studies}

The anti-inflammatory activity was evaluated by the carrageenan-induced paw oedema test in rats 22]. The left hind paw was injected with 0.2 $\mathrm{ml}$ of normal saline and used the control. Normal saline $(10 \mathrm{ml} / \mathrm{kg}$ ), the extract of Lobelia (250 and $500 \mathrm{mg} / \mathrm{kg}$ ) and aspirin (100 mg/kg) were orally administered $1 \mathrm{~h}$ prior to carrageenan injection $(0.1 \mathrm{ml} 2 \% \mathrm{w} / \mathrm{v}$ carrageenan in normal saline) to 4 different groups of rats $(n=6)$. The paw oedema sizes were recorded for each rat before carrageenan injection and at 1, 2, 3 and $4 \mathrm{~h}$ post carrageenan injection using Vernier Callipers.

\section{Anticonvulsant activity studies}

The anticonvulsant effect was evaluated using the pentylenetetrazole (PTZ)-induced convulsion model. Pentylenetetrazole $(85 \mathrm{mg} / \mathrm{kg})$ was used to induce tonic-clonic convulsions [23]. Five different groups $(n=5)$ of mice were randomly selected and orally pre-treated for $1 \mathrm{~h}$ as follows: group I received normal saline $(10 \mathrm{ml} / \mathrm{k})$, groups II-III received extract (500 and $1000 \mathrm{mg} / \mathrm{kg}$ ) respectively and group IV diazepam (1 mg/kg). 
Thereafter, anticonvulsant assessment was carried out with pentylenetetrazole $(85 \mathrm{mg} / \mathrm{kg}$, i.p.). The animals were observed for the onset of convulsion, time of death and mortality. Animals that survived beyond $30 \mathrm{~min}$ postpentylenetetrazole injection were regarded to be protected.

\section{Statistical analysis}

The results are expressed as mean \pm standard error of mean (SEM) and analysed using oneway analysis of variance (ANOVA) followed by post hoc test using Dunnett's test for comparison between the treated groups and control at $p<$ 0.05 ; while the ratio of mortality or protection for each group was expressed in percentage. The software used are GraphPad Instant $R$ version 3.0.10.0 (UK) and GraphPad Prism Version 5 2013 (GraphPad Software Inc).

\section{RESULTS}

\section{Yield of the essential oil and infusion extract}

The yield of the essential oil was $0.22 \% \mathrm{w} / \mathrm{w}$, which was light yellowish in colour with characteristic aromatic odour. The infusion extract obtained from the dried leaf of Lobelia weighed $25.54 \mathrm{~g}(25.50 \% \mathrm{w} / \mathrm{w}) .25 .54 \mathrm{~g}(25.5 \%$ $w / w)$.

\section{Phytochemical profile of the infusion extract of Lobelia flaccida leaf}

The results obtained from the qualitative screening of Lobelia leaf indicated the presence of alkaloids, flavonoids, phenols, phytosterols, proteins, saponins and tannins; while carbohydrates, glycosides, phlobatannins and steroids were not detected. The quantitative analysis of Lobelia leaf infusion extract showed that the percentage of alkaloid, saponins and flavonoids constituents were $2.40,0.14$ and 0.40 $\% \mathrm{w} / \mathrm{w}$ respectively while its tannin constituent was not recoverable.

\section{Composition of Lobelia essential oil}

GC/MS analysis of Lobelia essential oil indicated the presence of 25 compounds out of which 23 were fully identified constituting about $98 \%$ of all the constituents (Table 1). The major compounds identified include acetophenone (26.37\%), caryophyllene $(8.11 \%)$, borneol $(7.46 \%)$ and anethole $(6.81 \%)$.

Table 1: Chemical composition of the essential oil of $L$. flaccida

\begin{tabular}{|c|c|c|c|c|}
\hline $\begin{array}{l}\text { Peak } \\
\text { no }\end{array}$ & Compound $^{\mathrm{a,b}}$ & $\begin{array}{l}\text { Eluting time } \\
\text { (sec) }\end{array}$ & $\mathbf{K} \mathbf{I}$ & $\begin{array}{l}\text { Relative \% } \\
\text { composition }\end{array}$ \\
\hline 1 & a-Pinene & 5.205 & 937 & 1.40 \\
\hline 2 & Benzaldehyde & 5.710 & 957 & 5.36 \\
\hline 3 & 2-Pentylfuran & 6.210 & 989 & 1.15 \\
\hline 4 & 1,8-cienole & 7.225 & 1030 & 3.13 \\
\hline 5 & Acetophenone & 8.010 & 1065 & 26.37 \\
\hline 6 & Linalool & 8.760 & 1101 & 3.92 \\
\hline 7 & 2(10)-Pinen-3-ol, (1S, 3R, 5S) & 9.960 & 1138 & 0.47 \\
\hline 8 & Camphor & 10.135 & 1145 & 6.56 \\
\hline 9 & D-isomenthone & 10.310 & 1162 & 0.62 \\
\hline 10 & Borneol & 10.770 & 1169 & 7.46 \\
\hline 11 & a-Terpineol & 11.340 & 1195 & 2.35 \\
\hline 12 & (-)-Carvone & 12.650 & 1242 & 2.60 \\
\hline 13 & Anethole & 13.775 & 1142 & 6.81 \\
\hline 14 & Phenol,2-methyl-5-(1-methylethyl) & 14.050 & 1152 & 3.67 \\
\hline 15 & a-Terpineol acetate & 15.355 & 1347 & 1.31 \\
\hline 16 & Unidentified & 16.720 & & 0.55 \\
\hline 17 & Caryophyllene & 17.345 & 1436 & 8.11 \\
\hline 18 & Geranyl acetone & 17.865 & 1438 & 1.41 \\
\hline 19 & $\beta$-Humulene & 18.240 & 1483 & 1.87 \\
\hline 20 & (E)- $\alpha$-lonone & 18.750 & 1492 & 2.43 \\
\hline 21 & Cadina-1(10),4-diene & 19.740 & 1533 & 1.80 \\
\hline 22 & Caryophyllene oxide & 21.330 & 1588 & 3.43 \\
\hline 23 & Guaiol & 21.600 & 1601 & 3.13 \\
\hline 24 & Unidentified & 22.980 & & 0.62 \\
\hline 25 & 2-Pentadecanone,6,10,14-trimethyl & 26.845 & 1697 & 3.46 \\
\hline
\end{tabular}


The classes of compound identified in the oil were sesquiterpenes (8.11\%), phenyl alkenes $(6.81 \%)$, monoterpenes $(7.46 \%)$ and a simple ketone $(26.37 \%)$. The major compounds obtained were from different classes and they play different roles in the Lobelia but the major compound is an aromatic ketone acetophenone (26.37\%).

\section{Acute toxicity effect of the infusion extract of Lobelia dried leaf}

There was no mortality at all the doses of the infusion extract up to $5000 \mathrm{mg} / \mathrm{kg}, \mathrm{p} .0$. The $\mathrm{LD}_{50}$ was therefore estimated to be $\geq 5000 \mathrm{mg} / \mathrm{kg}$ through the oral route in mice.

\section{Effect of infusion extract of Lobelia leaf on carrageenan-induced rat paw oedema}

Rats pre-treated with normal saline had increased paw sizes throughout the 4-hour period of observation. Infusion extract of Lobelia, $250-500 \mathrm{mg} / \mathrm{kg}$ caused significant $(p<0.01)$ reduction in paw oedema sizes at 1, 2, 3 and $4 \mathrm{~h}$ post-carrageenan injection compared to control group. Also, aspirin $(100 \mathrm{mg} / \mathrm{kg}$ ) similarly caused significant $(p<0.01)$ reduction in the rats' paw oedema (Figure 1).

\section{Effect of the infusion extract of Lobelia leaf against PTZ-induced convulsion}

All the mice in the control group convulsed and died within $30 \mathrm{~min}$ post-PTZ (85 mg/kg, i.p.). The extract delayed the onset of convulsion and time of death after convulsion compared to vehicle although not statistically significant. Diazepam, (a standard anticonvulsant drug used) caused significant $(p<0.01)$ delay in onset of convulsion and protected the mice against PTZ-induced death. However, Lobelia at 500 and $1000 \mathrm{mg} / \mathrm{kg}$ offered 40 and $20 \%$ protections against the PTZinduced mortality respectively compared to the group's $0 \%$ and diazepam's $100 \%$ protection at 30 min observation period (Table 2).

\section{DISCUSSION}

Phytochemical screening of Lobelia leaf confirmed the presence of several metabolites including alkaloids, saponins, flavonoids, phenols, phytosterols, proteins and tannins.

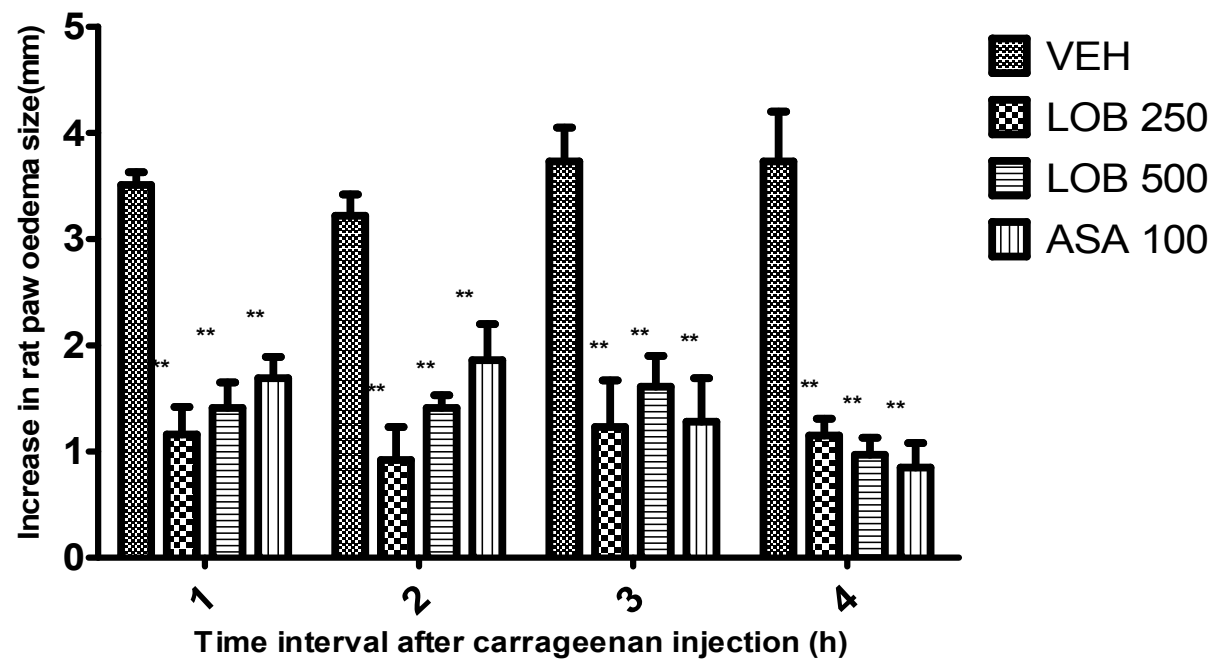

Figure 1: Effect of Lobelia leaf infusion on carrageenan induced rat paw oedema. Key: LOB 250: Lobelia infusion extract $250 \mathrm{mg} / \mathrm{kg}$, LOB 500: Lobelia infusion extract $500 \mathrm{mg} / \mathrm{kg}$, ASA: aspirin $100 \mathrm{mg} / \mathrm{kg}$ and VEH: normal saline; ${ }^{* *} p<0.01$; at $1 \mathrm{~h}, \mathrm{~F}_{(3,20)}=20$; at $2 \mathrm{~h}, \mathrm{~F}_{(3,20)}=14.7$; at $3 \mathrm{~h}, \mathrm{~F}_{(3,20)}=16.0$; at $4 \mathrm{~h}, \mathrm{~F}_{(3,20)}=22.9$

Table 2: Effect of the infusion extract of $L$. flaccida on PTZ-induced convulsion in mice

\begin{tabular}{|c|c|c|c|c|}
\hline Treatment & $\begin{array}{l}\text { Convulsion latency(s) } \\
\text { Mean } \pm \text { SEM }\end{array}$ & $\begin{array}{l}\text { Time of death (s) } \\
\text { Mean } \pm \text { SEM }\end{array}$ & \% Protection & $\%$ Mortality \\
\hline $\begin{array}{l}\text { Normal saline } \\
\text { Lobelia } 500 \mathrm{mg} / \mathrm{kg} \\
\text { Lobelia } 1000 \mathrm{mg} / \mathrm{kg} \\
\text { Diazepam } 1 \mathrm{mg} / \mathrm{kg}\end{array}$ & $\begin{array}{l}5.20 \pm 3.69 \\
161.4 \pm 92.30 \\
91.0 \pm 23.47 \\
1505 \pm 295.0^{* *} \\
\end{array}$ & $\begin{array}{l}349.4 \pm 94.4 \\
1038.0 \pm 354.6 \\
919.8 \pm 260.3 \\
1800 \pm 0.0^{.1}\end{array}$ & $\begin{array}{c}0 \\
40 \\
20 \\
100 \\
\end{array}$ & $\begin{array}{c}100 \\
60 \\
80 \\
0 \\
\end{array}$ \\
\hline
\end{tabular}

${ }^{* *} P<0.01, \mathrm{~F}_{(3,16)}=21$; statistically different from other groups; ANOVA, Dunnett's 
These phyto-constituents have variously been shown to be responsible for many bioactivities displayed by plants and new compounds can be discovered by probing them further. It must be noted however, that plant extract contains low concentrations of active compounds and a large number of promising compounds especially Lobelia species $[17,18]$. The essential oil analysis revealed the major compounds present in the Lobelia flaccida dried leaf to be acetophenone $(26.37 \%)$ caryophyllene $(8.11 \%)$, borneol $(7.46 \%)$ and anethole $(6.81 \%)$. There was scanty information in literature on the chemical composition of essential oil of this Lobelia specie. However, Joshi et al [15] reported that perilla ketone (25.61\%), camphorquinone (12.16\%), dibutyl phthalate $(10.66 \%)$ and allylnonanoate $(8.47 \%)$ were the main constituents of essential oil of Lobelia pyramidalis (Wall) from India. The oil composition in the present study is different in the class of compounds constituting it. Our report showed that there were more monoterpenes and sesquiterpenoids present as compared to that of Joshi et al [15].

Acute toxicity profile of the Lobelia flaccida dried leaf aqueous extract indicated an $L_{50}$ of $\geq 5000$ $\mathrm{mg} / \mathrm{kg}$, p.o., indicating that it is non-toxic [21]. This toxicity test result can be used to explain why the plant is a popular medicinal agent that has been used extensively over the years without report of serious adverse effects.

Carrageenan-induced paw oedema continues to be a valuable experimental animal model for acute inflammation which is strongly speculated to be biphasic viz. early phase (1-2 h) mediated by histamine and serotonin, and late phase $(>2$ h) mediated by bradykinin, leukotrienes and prostaglandins [26]. In this study, Lobelia extract significantly inhibited paw oedema induced by carrageenan in both phases, suggesting possible inhibition of release of inflammatory mediators and cyclooxygenase synthesis similarly to nonsteroidal antiinflammatory drugs such as aspirin, whose mechanism of action is inhibition of the cyclooxygenase pathway. The results obtained here support the ethno-medicinal claims ascribed to this particular plant species found in South Africa by the herbal practitioner. The screening of this plant extract showed high flavonoid content (4\% w/w) which has been previously linked to the antiinflammatory activity of $L$. chinensis [10], it can therefore be postulated here that the antiinflammatory activity of this Lobelia extract could be associated with the high flavonoids and or saponins present in it $[27,28]$.
The anticonvulsant test indicated that Lobelia infusion extract did not significantly alter the onset of convulsion or time of death compared to the vehicle, but it did prolong insignificantly the latency and time of death caused by the PTZ compared to the vehicle. Previous studies have indicated that the extract of this plant showed anticonvulsant potentials in many models of convulsion and lobeline isolated from the leaf of L. nicotianaefolia demonstrated significant anticonvulsant activity [29]. Considering the fact that it was just the infusion extract that was used in this study, extraction with other solvents such as ethanol would probably have demonstrated greater anticonvulsant activity because more bioactive substances would be extracted. Also, the essential oil component which was not tested against convulsion due to low quantity obtained in this study may exhibit greater activity since essential oils of many plants demonstrate anticonvulsant activities [43].

\section{CONCLUSION}

The major component found in the essential oil of this $L$. flaccida species is caryophyllene. The infusion extract is non-toxic, possesses strong anti-inflammatory activity but mild anticonvulsant activity. Thus justifies the plant's use in traditional medicine to treat pain and rheumatism.

\section{DECLARATIONS}

\section{Acknowledgement}

This study was funded by NRF research grant no. 82640 (IKS 2012.01.19_10163). We also K Immelman (KEI herbarium) for her assistance in identifying the medicinal plant material.

\section{Conflict of Interest}

No conflict of interest associated with this work.

\section{Contribution of Authors}

The authors declare that this work was done by the authors named in this article and all liabilities pertaining to claims relating to the content of this article will be borne by them.

\section{REFERENCES}

1. Lee $\mathrm{KH}$. Current developments in the discovery and design of new drug candidates from plant natural product lead. J Nat Prod 2004; 67: 273-283. 
2. Newman DJ, Cragg GM, Snader KM. Natural products as sources of new drugs over the period 1981-2002. Journal of Natural Products 2003; 66(7): 1022-1037.

3. Jones WP, Chin Y-W, Kinghorn $A D$. The role of pharmacognosy in modern medicine and pharmacy. Current Drug Targets 2006; 7: 247-264.

4. Edeoga HO, Okwu DE, Mbaebie BO. Phytochemical constituents of some Nigerian medicinal plants. African Journal of Biotechnology 2005; 4: 685-688.

5. Felpin FX, Lebreton J. History, chemistry and biology of alkaloids from Lobelia inflate. Tetrahedron 2004; 60: 10127-10153.

6. Leistner OA. Seed plants of Southern Africa: families and genera. Pretoria; Strelitzia10; National Botanical Institute; 2000.

7. Cupido CN, Conrad F. Lobelias in South Africa. Veld \& Flora 2001; 83: 118-119.

8. Germishuizen G, Meyer NL. Plants of Southern Africa: an annotated checklist. Pretoria; National Botanical Institute 2003; 14: 941.

9. Dold AP, Cocks ML. Preliminary list of Xhosa plant names from the Eastern Cape, South Africa. Bothalia 1999; 29(2): 267-292.

10. Yang S, Shen T, Zhao L, , Li C, Zhang Y, Lou H, Ren D. Chemical constituents of Lobelia chinensis. Fitoterapia 2014; 93: 168-174.

11. Chen M, Chen W, Zhang J, Long X, Wang Y. Lobelia chinensis: Chemical constituents and anticancer activity perspective. Chin J Nat Med 2014; 12(2): 103-107.

12. Vigneshwaran V, Somegowda M. Pramod SN. Pharmacological Evaluation of Guédon, MF. Sacred Smudging in North America; Walkabout Press. (2000).

13. Glover ED, Rath JM, Sharma E, Glover PN, Laflin M, Tonnesen P, Repsher L, Quiring J.A multicenter phase 3 trial of lobeline sulfate for smoking cessation. Am J Health Behav2010; 34(1): 101-109.

14. Han J, Zhang F, Li Z, Du G, Qin H. Chemical constituents of Lobelia chinensis [J]. Chin Tradit Herbal Drugs 2009; 34(17): 2200-2202.

15. Joshi S, Mishra D, Bisht G, Khetwal KS. Essential oil composition and antimicrobial activity of Lobelia pyramidalis Wall. EXCLI 2011; 10: 274-279.

16. Subarnas A, Oshima Y, Sidik, Ohizumi Y. An antidepressant principle of Lobelia inflata (Campanulaceae). J Pharm Sci 1992); 53(7): 620-621.

17. Tamboli AM, Rub RA, Ghosh P, Bodhankar S. Antiepileptic activity of lobeline isolated from the leaf of
Lobelia nicotianaefolia and its effect on brain GABA level in mice. Asian Pac. J. Trop Biomed 2012; 2(7): 537-542.

18. Cocks ML, Moller V. Use of indigenous and indigenised medicines to enhance personal well-being: a South African case study. SocSci Med 2002; 54: 387-397.

19. Vigneshwaran V, Somegowda M. Pramod SN. Pharmacological Evaluation of Analgesic and Antivenom Potential from the Leaves of Folk Medicinal Plant Lobelia nicotianaefolia. AJPCT 2014; 2(12): 1404-1415.

20. Mir AM, Sawhney SS, Jassal MMS. Qualitative and quantitative phytochemical screening of Tarraxacum officinale. Wudpecker J Pharm Pharmacol 2013; 2(1): 001-005.

21. Lorke D. A new approach to practical acute toxicity testing. Arc Toxicol 1983; 54: 275-287.

22. Olajide AO, Awe SO, Makinde JM, Ekhelar Al, Olusola A, Morebise O, Okpako DT. Studies on the antiinflammatory, antipyretic and analgesic properties of Alstonia boonei stern bark. J. Ethnopharmacol 2000; 71: 179-186.

23. Swinyard EA, Woodhead JH, White HS, Franklin MR. Experimental selection qualification and evaluation of anticonvulsants. In: Levy R, Mattaon R, Meldrum BS, Penry JK, Dreifuss FE (Eds) Antiepileptic Drugs, 3rded. New York: Raven Press; 1989; pp 85-102.

24. Adams RP. Identification of Essential Oil Components: GC/Mass Spectroscopy. 4th Ed. USA; Allured Publishing Corporation, 336 Gunderson Drive, Suite A, Carol Stream, IL; 2007.

25. ESO 2000. The Complete Database of Essential Oils. The Netherlands; Boelens Aroma Chemical Information Service; 1999.

26. Vane JR, Botting RM. New insights into the mode of action of anti- inflammatory drugs. Inflammation Research 1999; 44(1): 1-10.

27. Kuo PC, Hwang TL, Lin YT, Kuo Y-C, Leu Y-L. Chemical constituents from Lobelia chinensis and their anti-virus and anti-inflammatory bioactivities [J]. Arch Pharm Res2011; 34(5): 715-722.

28. Damas J, Bourdon V, Remacle-Volon G, Lecomte J. Proinflammatory flavonoids which are inhibitors of prostaglandin biosynthesis. Prostaglandins Leuko Med 1985); 19: 11-24.

29. de Almeida RN, Agra Mde F, Maior FN, de Sousa DP. Essential oils and their constituents: anticonvulsant activity. Molecules 2011; 16(3): 2726-2742. 